\title{
MITOCHONDRIAL MECHANISMS OF APOPTOSIS IN CASE OF EXPERIMENTAL COMBINED TRAUMA OF THE CHEST AND BOTH THIGHS
}

\section{Mariya MARUSHCHAK ${ }^{1}$, Inna KRYNYTSKA ${ }^{1}$, Maksym KHUDOBIAK $^{1}$, Sergii VERNYGORODSKYI ${ }^{2}$, Lyudmyla MAZUR ${ }^{3}$}

${ }^{1}$ I. Horbachevsky Ternopil State Medical University, Functional and Laboratory Diagnostics Department, Ternopil, Ukraine

${ }^{2}$ Vinnytsya National Pirogov Memorial Medical University, Department of Pathological Anatomy, Forensic Medicine and Law, Vinnytsya, Ukraine

${ }^{3}$ I. Horbachevsky Ternopil State Medical University, Clinical Immunology, Allergology and General Patient Care Department, Ternopil, Ukraine

*All the authors contributed equally to this study and share the first authorship

Received 09 Sept 2018, Accepted 30 Oct 2018

https://doi.org/10.31688/ABMU.2018.53.4.05

\section{Abstract}

The objective of the study was to investigate the features of blood neutrophils' apoptosis in case of combined trauma of the chest and both thighs in rats.

Material and methods. The analysis of cell samples to determine reactive oxygen species was evaluated by the flow laser cytometry method, using 2.7-dichlorodihydrofluorescein diacetate. The percentage of neutrophils with low transmembrane mitochondrial potential and percentage of apoptotic neutrophils were evaluated by the flow laser cytometry method, using specific kits.

Results. It was established the progressive, statistically significant increasing of Annexin V-positive cells percentage from the first day of the experiment, with the highest values within 7-14 days of observation. On the $28^{\text {th }}$ day of experiment, the reduction of apoptotic

\section{Résumé}

Mécanismes mitochondriaux de l'apoptose en cas de traumatisme combiné expérimental de la poitrine et des deux cuisses

L'objectif de l'étude. Cette étude vise à étudier les caractéristiques de l'apoptose des neutrophiles sanguins en cas de traumatisme combiné de la poitrine et des deux cuisses chez le rat.

Méthodes. L'analyse des échantillons cellulaires pour déterminer les espèces réactives de l'oxygène a été évaluée par la méthode de la cytométrie en flux avec un diacétate de 2.7-dichlorodihydrofluorescéine. Le pourcentage de neutrophiles à faible potentiel mitochondrial transmembranaire et le pourcentage de neutrophiles apoptotiques ont été évalués par la méthode de cytométrie en flux avec des kits spécifiques. 
white blood cells percentage by $7.7 \%$ than the findings on the $14^{\text {th }}$ day was observed, but it remained $33.3 \%$ higher than the control.

Conclusion. One of the important signaling pathways of apoptosis triggering in case of experimental combined trauma of the chest and both thighs is reactive oxygen species overproduction and disruption of the mitochondrial inner membrane, due to the decreasing transmembrane potential on $3-7$ days of observation.

Keywords: closed pneumothorax, skeletal injury, rats, cell death.

\section{INTRODUCTION}

Structural and functional alteration of mitochondria plays an important role in the pathogenesis of many diseases, since mitochondria, as a semiautonomous organelle in cells, apart from containing their own genetic material, plays an important role in energy metabolism, oxidation-reduction balance and calcium homeostasis, pathways of mitochondria-mediated or receptor-independent apoptosis, provides mechanisms of signal transduction in the control of nuclear function ${ }^{1-6}$.

The molecular mechanisms of apoptosis involve several pathways and activation of caspases, a family of cysteine proteases, represents a common event for several pro-apoptotic stimuli? Regarding the characterization of the events upstream from caspase activation, mitochondrial damage has been reported to trigger this process. Consistent with this hypothesis, anti-apoptotic proteins, such as Bcl-2, are located in the mitochondria, suggesting a role for this organelle in the induction of apoptotic death. Moreover, the release of mitochondrial pro-apoptotic factors, such as cytochrome c, is blocked by $\mathrm{Bcl}-2^{8}$.

Excessive mitochondrial $\mathrm{Ca}^{2+}$ uptake is of particular importance in the brain, heart and muscle, where prolonged unphysiological increases in $\mathrm{Ca}^{2+}$ influx, especially when combined with oxidative stress, may result in a pathological transformation - the opening of the mitochondrial permeability transition pore (mPTP) and induction of necrotic cell death ${ }^{2,4}$.

Oxygen is used to support mitochondrial respiration, which in turn is used to build a proton gradient across the expanded surface area of the cristae.
Résultats. On a établi l'augmentation progressive et statistiquement significative du pourcentage des cellules d'Annexine V-positives à partir du premier jour de l'expérience avec les valeurs les plus élevées dans les 7 à 14 jours suivant l'observation. Le 28e jour de l'expérience, la réduction du pourcentage de globules blancs apoptotiques de $7.7 \%$ par rapport aux résultats du 14ème jour a été observée, mais elle est restée $33.3 \%$ supérieure à celle du témoin.

Conclusion. Ainsi, l'une des voies de signalisation importantes du déclenchement de l'apoptose en cas de traumatisme combiné expérimental de la poitrine et des deux cuisses est la surproduction et la rupture de la membrane mitochondriale interne dues à la diminution du potentiel transmembranaire après $3-7$ jours d'observation.

Mots-clés: pneumothorax fermé, lésion squelettique, rat, mort cellulaire.

It is the proton gradient, expressed largely as a mitochondrial transmembrane potential gradient, that then drives much of mitochondrial physiology - the synthesis of adenosine triphosphate (ATP), the transfer of calcium and other ion exchangers, and the import of proteins $s^{4,8}$.

Studies show that, in case of hypoxia, free oxygen radicals have been accumulated and can damage polyunsaturated fatty acids of cell membranes. This process is accompanied by disruption of their bioelectrical activity?.

The results of our previous studies point to the development of tissue hypoxia in early posttraumatic period in case of combined trauma of the chest and both thighs in rats. We also have shown the increasing of reactive oxygen species contents in the blood leukocyte suspension in 24 hours of posttraumatic period with progressive dynamics ${ }^{10}$. Analyzing the own results and published data, we have suggested that damage of the cell plasma membrane is accompanied by their apoptotic death.

The obJective OF OUR STUdY was to establish the features of blood neutrophils' apoptosis in case of combined trauma of the chest and both thighs in rats.

\section{Materials AND Methods}

Experimental studies were conducted on 70 male, nonlinear, white rats of 200-210 g body weight, that were housed at $25 \pm 3^{\circ} \mathrm{C}$ and humidity of $55 \pm 2$ $\%$, under a constant $12 \mathrm{~h}$ light and dark cycle. Water was available ad libitum. 
The animals were randomly divided into 6 groups: 1 control (C) and 5 experimental (E1, E2, E3, E4, E5): E1 - combined trauma of the chest and both thighs, 24 hours of observation; E2 - combined trauma of the chest and both thighs, 3 days of observation; E3 - combined trauma of the chest and both thighs, 7 days of observation; E4 - combined trauma of the chest and both thighs, 14 days of observation; E5 - combined trauma of the chest and both thighs, 28 days of observation.

Experimental animal mortality: 11 rats.

Right sided closed pneumothorax with rib fracture, which was combined with a broken left and right femur, was modelled using a trocar to the animals of the experimental groups under the sodium thiopental anesthesia $(40 \mathrm{mg} / \mathrm{kg}$ of the animal weight). Skeletal injury was modelled by applying a single dosed impact by specially designed device on each thigh, which caused a closed fracture ${ }^{11}$. Impact energy was $0.375 \mathrm{~J}$, which corresponded to the injury of moderate severity. Combined injury was modelled by sequential application of the two injuries.

In 24 hours, 3rd, 7th, 14th and 28th days, euthanasia was performed for rats by administration of sodium thiopental, $90 \mathrm{mg} / \mathrm{kg}$ of the animal weight in accordance with the requirements of the Animal Care Committee.

The population of neutrophils was obtained by blood centrifugation at double density gradient 1.077 and 1.093 of ficoll-urografin. After 40 minutes of centrifugation at $4^{\circ} \mathrm{C}$ and the speed of $1500 \mathrm{rpm}$, two interphases were formed. Upper interphase (on the border of plasma - ficoll-urografin density 1.077) was consisted of mononuclear cells - $80 \%$ of lymphocytes, $15-18 \%$ of monocytes and $2-3 \%$ of granulocytes. Lower interphase (on the border of solutions gradient density 1.077-1.092) was the population of neutrophils ${ }^{12}$. The number of viable cells present in a cell suspension was 98-99\% (Trypan blue exclusion test).

To determine the level of neutrophils' apoptosis, the leukocyte blood suspension was resuspended in a pre-diluted (1:10) binding buffer from the kit of reagents"ANNEXIN V FITC" ("Beckman Coulter", USA). The number of cells was counted with the help of Goryaev's calculating camera under the microscope and adjusted to the number of $1 \times 10^{6}$ cells $/ \mathrm{ml}$. Then, $100 \mu \mathrm{L}$ of cell suspension was taken to test tube and $1 \mu \mathrm{L}$ of annexin V-FITC solution and $5 \mu \mathrm{L}$ of dissolved PI were added. Cells were mixed and incubated in binding buffer at room temperature. As a negative control, we have used unlabeled cells. The determination of apoptosis was conducted on flow cytometer Epics XL (Beckman Coulter, USA), using a software system. Results are expressed as a percentage of cells which have attached FITC Annexin V or PI.
The cells are alive when they are FITC Annexin V and PI negative. The cells are apoptotic when they are FITC Annexin V positive and PI negative. The cells are in stage of irreversible apoptosis (necrosis) when they are FITC Annexin V positive and PI positive.

The analysis of cell samples to determine ROS (hydrogen peroxide) of neutrophils was evaluated by the flow laser cytometry method on flow cytometer Epics XL (Beckman Coulter, USA), using 2.7-dichlorodihydrofluorescein diacetate. The value of the studied parameter was expressed as a percentage (ratio of cells with ROS overproduction to general cell count $\times 100 \%$ ).

The number of neutrophils with low transmembrane mitochondrial potential $(\Delta \psi)$ was evaluated by the flow laser cytometry method, using a kit of reagents "MitoScreen» («BD Pharmigen», USA) on flow cytometer Epics XL (Beckman Coulter, USA). The value of the studied parameter was expressed as a percentage (ratio of cells with low $\Delta \psi$ to general cell count $\times 100 \%)$.

All procedures were conducted according to the European Convention for the Protection of Vertebrate Animals used for Experimental and Other Scientific Purposes (Strasbourg, 1986) and General Ethical Principles of Experiments using Animals (First National Congress of Bioethics, Kyiv, 2001) ${ }^{13}$.

All of the data were processed using the software package Statistica 6.1 for Windows. Intergroup comparisons were performed using Mann-WhitneyWilcoxon $\mathrm{U}$ test. The median (Me) and interquartile range (IQR [Q25-Q75]) were deduced. Correlation analysis was performed by Spearman method. The coefficient of linear correlation ( $\mathrm{r}$ ) and its reliability (p) were calculated, which was accordingly denoted in the tables (correlation matrices). If the index $r=0$, the linkage was considered as absent, in the range 0-0.29 - the linkage was considered as weak correlation, interval of index 0.30-0.69 described linkage as medium strength and interval $0.70-1.00$ pointed to strong correlation interaction. The correlation coefficient was significant at $p<0.05$.

\section{Results}

The analysis of data indicates that production of ROS by neutrophils in case of combined trauma of the chest and both thighs in rats has increased: in 24 hours by 2.5 times, in the $3^{\text {rd }}$ day by 2.8 times, reaching a maximum in $7^{\text {th }}$ day when this index was 3.2 times higher vs control group (Table 1). Although production of ROS by neutrophils in subsequent periods of observation (14 and 28 days) had decreased by $11.0 \%$ vs data of the $7^{\text {th }}$ day, it remained 2.8 times greater vs control group. 
Table 1. The indices of mitochondrial apoptosis pathway in case of combined trauma of the chest and both thighs (Me [Q25-Q75])

\begin{tabular}{|c|c|c|c|}
\hline Index & $\begin{array}{l}\text { The percentage of reactive } \\
\text { oxygen species of neutrophils }\end{array}$ & $\begin{array}{l}\text { The percentage of neutrophils with low } \\
\text { transmembrane potential }\end{array}$ & $\begin{array}{c}\text { The percentage of FITC } \\
\text { Annexin V-positive neutrophils }\end{array}$ \\
\hline Control group, $(n=10)$ & $\begin{array}{c}17.7 \\
{[17.4 ; 18.1]}\end{array}$ & $\begin{array}{c}1.3 \\
{[1.2 ; 1.6]}\end{array}$ & $\begin{array}{c}5.4 \\
{[5.1 ; 5.8]} \\
\end{array}$ \\
\hline \multirow[t]{2}{*}{$\begin{array}{l}\text { Experimental group 1, } \\
(\mathrm{n}=11)\end{array}$} & $\begin{array}{c}42,6^{*} \\
{[41.9 ; 42.6]}\end{array}$ & $\begin{array}{c}1,5^{*} \\
{[1.4 ; 1.6]} \\
\end{array}$ & $\begin{array}{c}6,2^{*} \\
{[6.1 ; 6.6]}\end{array}$ \\
\hline & $\mathrm{p} \leq 0,001$ & $\mathrm{p} \leq 0,001$ & $\mathrm{p}=0,01$ \\
\hline \multirow[t]{2}{*}{$\begin{array}{l}\text { Experimental group } \\
2,(\mathrm{n}=9)\end{array}$} & $\begin{array}{c}48.7^{*} \\
{[46.1 ; 50.5]}\end{array}$ & $\begin{array}{c}2.6^{*} \\
{[2.5 ; 2.8]} \\
\end{array}$ & $\begin{array}{c}6.6^{*} \\
{[6.4 ; 6.8]} \\
\end{array}$ \\
\hline & $\mathrm{p} \leq 0,001$ & $\mathrm{p} \leq 0,001$ & $\mathrm{p} \leq 0,001$ \\
\hline \multirow[t]{2}{*}{$\begin{array}{l}\text { Experimental group } 3, \\
(\mathrm{n}=10)\end{array}$} & $\begin{array}{c}56.5^{*} \\
{[54.7 ; 57.8]}\end{array}$ & $\begin{array}{c}3.5^{*} \\
{[3.2 ; 3.9]}\end{array}$ & $\begin{array}{c}7.8^{*} \\
{[7.4 ; 8.1]}\end{array}$ \\
\hline & $\mathrm{p} \leq 0,001$ & $\mathrm{p} \leq 0,001$ & $\mathrm{p} \geq 0,05$ \\
\hline \multirow[t]{2}{*}{$\begin{array}{l}\text { Experimental group } \\
4,(\mathrm{n}=9)\end{array}$} & $\begin{array}{c}50.1^{*} \\
{[47.5 ; 51.9]} \\
\end{array}$ & $\begin{array}{c}3.0^{*} \\
{[2.8 ; 3.2]}\end{array}$ & $\begin{array}{c}7.8^{*} \\
{[7.5 ; 7.9]} \\
\end{array}$ \\
\hline & $\mathrm{p} \geq 0,05$ & $\mathrm{p} \leq 0,01$ & $\mathrm{p} \leq 0,001$ \\
\hline $\begin{array}{l}\text { Experimental group 5, } \\
\qquad(\mathrm{n}=10)\end{array}$ & $\begin{array}{c}50.5^{*} \\
{[48.4 ; 51.8]}\end{array}$ & $\begin{array}{c}2.6^{*} \\
{[2.4 ; 2.7]}\end{array}$ & $\begin{array}{c}7.2^{*} \\
{[7.1 ; 7.2]}\end{array}$ \\
\hline
\end{tabular}

Note: ${ }^{*}$ - significant differences compared to control animals, $\mathrm{p}<0.05$;

$\mathrm{p}$ - significant differences between the experimental groups.

The same trend is observed for changing the percentage of white blood cells with low transmembrane mitochondrial potential. Thus, the maximum value of the investigated index was detected after the $7^{\text {th }}$ day of the experiment, exceeding by 2.6 times the data of control group. In spite of the fact that after 28 days of experiment the percentage of white blood cells with low $\Delta \psi$ was significantly lower compared to data of second and third experimental groups, it exceeded twice the control data.

To investigate the mechanism of apoptosis onset, the percentage of Annexin V-positive cells was determined. It was established the progressive, statistically significant increasing of Annexin $\mathrm{V}$ - positive cells percentage from the first day of the experiment, with the highest values within 7-14 days of observation.

During this period, the investigated index was $44.4 \%$ higher than the data of the control group. On the $28^{\text {th }}$ day of experiment, the reduction of apoptotic white blood cells percentage by $7.7 \%$ than the findings on $14^{\text {th }}$ day was observed, but it remained $33.3 \%$ higher than the control group.

Two known ways of apoptosis include internal or mitochondrial, involving protein family $\mathrm{Bcl}-2, \mathrm{cy}$ tochrome $\mathrm{C}$ and caspase - 9 and external with the activation of caspase -8 linking a specific cell receptor Fas- and soluble tumor necrosis factor receptors on the cell surface ${ }^{14}$, but our objective was to assess the impact of the mitochondrial pathway. Analyzing the dynamics of the investigated parameters, interdependence of changes can be seen. Thus, in 24 hours after combined trauma of the chest and both thighs in rats, the production of free radicals increases, the source of which, in our opinion, is not only mitochondria. In 3 days of experiment, bioelectric activity of mitochondrial membranes is disrupted under the influence of reactive oxygen species, leading to the decreased of transmembrane potential. Accordingly, we consider that the most critical period in apoptotic destruction triggering in case of combined trauma is the $7^{\text {th }}$ day, when pro-apoptotic factors are going out into the cell and lead to its death. In 14 days of experiment, the production of reactive oxygen species is stabilized, reducing the negative impact on the mitochondria and the cell. Up to the $28^{\text {th }}$ day, essential, protective functions of the organism are restored, which leads to reduction of negative influence of oxygen radicals on cells (Figure 1).

The conducted correlative analysis showed statistically significant, medium strength linkage, between ROS and the percentage of FITC Annexin V-positive cells in all periods of observation, except the $14^{\text {th }}$ day (Table 2). It should be noted that there is a significant interdependence between the percentage of cells with low transmembrane potential and apoptosis in 3 and 7 days after combined trauma of the chest and both thighs in rats.

\section{Discussion}

Summarizing the findings, we can talk about the triggering of apoptotic cell death due to ROS overproduction and disruption of the mitochondrial inner membrane, due to the decreasing of transmembrane 


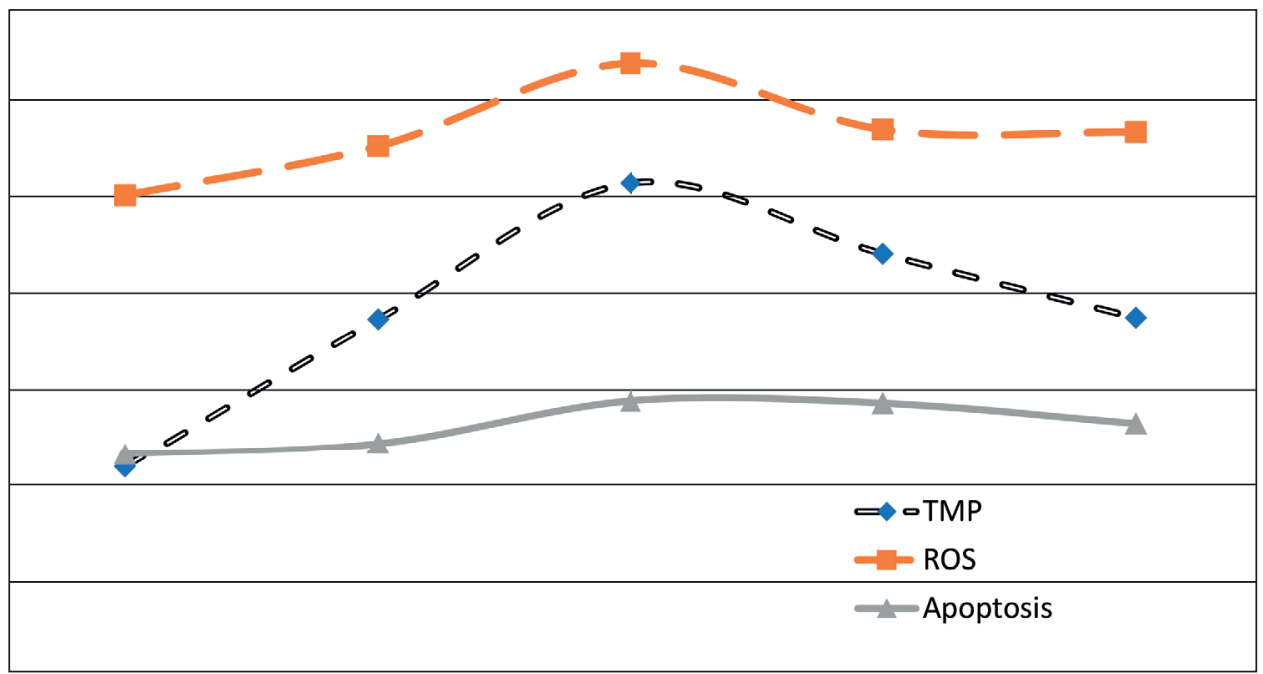

Figure 1. The dynamics of the mitochondrial apoptosis pathway in case of combined trauma of the chest and both thighs.

Table 2. Correlative linkages between the percentage of FITC Annexin V-positive cells of leukocyte suspension with ROS and mitochondrial transmembrane potential in case of combined trauma of the chest and both thighs $\left(\mathrm{r}_{\mathrm{xy}}\right)$

\begin{tabular}{|c|c|c|c|c|c|}
\hline \multirow{2}{*}{ Index } & \multicolumn{5}{|c|}{ The percentage of reactive oxygen species of neutrophils } \\
\hline & 24 hours & 3 days & 7 days & 14 days & 28 days \\
\hline \multirow{4}{*}{$\begin{array}{l}\text { The percentage of } \\
\text { FITC Annexin V-posi- } \\
\text { tive neutrophils }\end{array}$} & $0.52^{*}$ & $0.56^{*}$ & $0.56^{*}$ & 0.31 & $0.57^{*}$ \\
\hline & \multicolumn{5}{|c|}{ The percentage of cells of leukocyte suspension with low transmembrane potential } \\
\hline & 24 hours & 3 days & 7 days & 14 days & 28 days \\
\hline & 0.23 & $0.63^{*}$ & $0.70^{*}$ & 0.36 & 0.43 \\
\hline
\end{tabular}

Note: * - significant differences of correlation coefficients, $p<0.05$

potential in 3-7 days after combined injury of the chest and both thighs. This statement demonstrates the role of mitochondrial apoptotic death initiation pathway in case of experimental combined trauma of the chest and both thighs, but does not deny the importance of other signaling pathways of apoptosis triggering. It should be noted that in 14 days of observation mitochondrial apoptosis mechanisms are devalued, but increased percentage of FITC Annexin $V$ - positive cells remained.

So, in case of experimental combined trauma of the chest and thighs a "vicious circle" has developed, which is associated with energy deficiency ${ }^{10}$ and overproduction of free radicals, on the background of hypoxia. Superoxide anion is produced the most actively by mitochondria. It has a very short half-life, but in the presence of superoxide dismutase it is transformed into oxygen and hydrogen peroxide, the level of which we have found via 2.7-dichlorodihydrofluorescein diacetate by flow cytometry. $\mathrm{H}_{2} \mathrm{O}_{2}$ itself is relatively inactive, but can lead to the formation of toxic hydroxyl radicals $(\bullet \mathrm{OH})$. Fenton showed that the formation of toxic hydroxyl radicals $(\bullet \mathrm{OH})$ from hydrogen peroxide is catalyzed by iron ions, called the „Fenton reaction“. Weiss and Haber discovered that $\mathrm{O}_{2} \bullet$ can be converted into $\mathrm{H}_{2} \mathrm{O}_{2}$ and further to $\bullet \mathrm{OH}$, called the Haber-Weiss reaction ${ }^{15-17} \cdot \bullet \mathrm{OH}$ are strong oxidants of biopolymers and lipids, inducing processes of lipid peroxidation, disruption of membrane structures, leading to cell death and increasing of energy deficiency ${ }^{18,19}$.

\section{Conclusions}

In post-traumatic period of combined trauma of the chest and both thighs in rats, the statistically significant overproduction of reactive oxygen species by blood neutrophils in 24 hours of experiment leads to disruption of mitochondrial membrane bioelectrical activity. This process is characterized by dynamic increasing of the percentage of neutrophils, with low transmembrane potential with a maximum in $7^{\text {th }}$ day (exceeding by 2.6 times the data of control group, $\mathrm{p} \leq 0.001$ ). It was established the progressive, statistically significant increasing of the percentage of apoptotic neutrophils, from the first day of the 
experiment, with the highest values within the 7-14 days of observation.

In case of experimental combined trauma of the chest and both thighs, we have established statistically significant, medium strength linkage between ROS and the percentage of FITC Annexin V-positive cells in all periods of observation, excepting the $14^{\text {th }}$ day $(p \leq 0.05)$; significant interdependence between the percentage of cells with low mitochondrial transmembrane potential and apoptosis in 3 days $\left(\mathrm{r}_{\mathrm{xy}}=0.63\right)$ and 7 days $\left(r_{x y}=0.70\right)$ of observation.

\section{Acknowledgements:}

This research was partially supported by the Rector of I. Horbachevsky Ternopil State Medical University. We thank our colleagues from University Research Laboratory, who provided insight and expertise that greatly assisted the research.

\section{Compliance with Ethics Requirements:}

"The authors declare no conflict of interest regarding this article"

„The authors declare that all the procedures and experiments of this study respect the ethical standards in the Helsinki Declaration of 1975, as revised in 2008(5), as well as the national law."

„All institutional and national guidelines for the care and use of laboratory animals were followed"

\section{References}

1. Gogvadze V, Orrenius S, Zhivotovsky B. Mitochondria in cancer cells: what is so special about them? Trends Cell Biology 2008;18(4): 165-173.

2. Duchen MR. Mitochondria and calcium: from cell signaling to cell death. Journal of Physiology 2000;529: 57-68.

3. Kaplia AA, Sorokina LV, Khyzhnyak SV. Reprogramming of mitochondrial energy metabolism in malignant neoplasms. The Ukrainian Biochemical Journal 2015;87(6): 19-35.
4. Osellame LD, Blacker TS, Duchen MR. Cellular and molecular mechanisms of mitochondrial function. Best Pract Res Clin Endocrinol Metabolism 2012;26(6): 711-723.

5. Hongmei Z. Extrinsic and intrinsic apoptosis signal pathway review. Apoptosis and Medicine. InTech 2012, doi: $10.5772 / 50129$

6. Moisă C, Găman MA, Pascu EG, et al. The role of oxidative stress in essential thrombocythemia. Arch Balk Med Union 2018;53(1): 70-75.

7. Marushchak M, Krynytska I, Milevska L, Miz A, Mialiuk O. The changes of activity of effector caspase cascade components in case of alimentary obesity in rats. Bangladesh Journal of Medical Science 2017;16(02): 248-254.

8. Oset-Gasque MJ, Fuentes MP, Vicente S, Figueroa S, Rocío P-R, Pilar GM. Mitochondrial mechanisms involved in nitric oxide (NO)-induced apoptosis in bovine chromaffin cells in primary culture. Cell Biology of the Chromaffin Cell, Instituto Teófilo Hernando, Spain 2004.

9. Weir EEK, Reever JT. Pulmonary Vascular Physiology and Pathophysiology. New York: Marcel Dekker 2009: 241-290.

10. Khudobyak MM. The ways of free radical oxidation correction in the early posttraumatic period after the combined trauma of the chest and hips. Medical and Clinical Chemistry 2016;18(1): 108-111. [in Ukrainian].

11. Kozak DV. Method of modeling of polytrauma. Patent of Ukraine 2011; 201104110. [in Ukrainian].

12. Roth JA, Kaeberle ML. Isolation of neutrophils and eosinophils from the peripheral blood of cattle and comparison of their functional activities. J Immunol Methods 1981;45(2): 153-164.

13. European convention for the protection of vertebrate animals used for experimental and other scientific purposes. Council of Europe. Strasbourg 1986;123: 52.

14. Illinska IF. Apoptosis, apocytosis and their role in the immune response (analytical review) Lab diahnostyka 2002;3: 66-72. [in Russian].

15. Weidinger A, Kozlov AV. Biological activities of reactive oxygen and nitrogen species: oxidative stress versus signal transduction. Biomolecules 2015;5: 472-484.

16. Kehrer JP. The Haber-Weiss reaction and mechanisms of toxicity. Toxicology 2000;149:43-50.

17. Koppenol WH. The centennial of the Fenton reaction. Free Radic Biol Med 1993;15: 645-651.

18. Demikhova N, Sukhonos V, Vynnychenko L, Psareva V, Prikhodko O. Activation of lipid peroxidation in patients with renal hypertension. Georgian Med News 2013;(215): 51-55.

19. Hamanaka R, Chandel S. Mitochondrial reactive oxygen species regulate cellular signaling and dictate biological outcomes. Trends Biochem Sci 2010;35(9): 505-513. 